\title{
Morphosolation characteristic of the flower of liliaceae rare species of the Namangan region of the areal distribution Foziljonov Shukrullo ${ }^{1}$
}

\author{
${ }^{1}$ Student of Andijan State University \\ Email:shukrullofoziljonov@gmail.com
}

\begin{abstract}
The study of species of rare plants in the Fergana Valley suggests that the representatives of the taxis Lilliaceae form a large proportion of such species. The purpose of this theoretical work, taking into account the large area of the distribution area across the valley by family representatives Namangan and the factor of the reduction of this family, is aimed at studying the flower structure, which is the main morphofunctional cognition of the representatives of the liliaceae rare scattered throughout the Namangan region and their comparative analysis.
\end{abstract}

Keywords: rare plants, liliaceae, Red book, Fergana valley, Tulipa 'Ancilla' (Kaufmanniana Tulip), Tulipa dubia, Tulipa greigi, Tulipa scharipovii, Tajibaev, Flora, endemic species

\section{INTRODUCTION}

Geographically, the Fergana Valley includes Andijan, Fergana and Namangan provinces. The Red Book includes 1 from Andijan, 27 from Fergana and Namangan 12 plant species are included. As far as possible, the area where the vegetation is distributed should be analyzed on a small scale.[Shukrullo]. Astragalus and Tulpan are some of the rare plants in the Fergana Valley. Half of the 12 species in the given Namangan region belong to the tulip species. Due to its beautiful appearance, the growing season does not end or Excavation with a tube (onion, stem and rootstock): Holmon isirgaguli (Fritillaria eduardi Regel) and representatives of all tulip families (liliaceae). This is to create cultural representatives of the tour and to preserve the rare species in the network. In this case, it is necessary to establish research fields in the areas of distribution. For example Due to the successful cultivation of the Holman hyacinth, it is declining and disappearing the risk of departure is sharply reduced..

Fig.1. The ratio of tulip species to the total number of Fergana Valley and Namangan region=[Fergana valley, Namangan, Tulipa.]

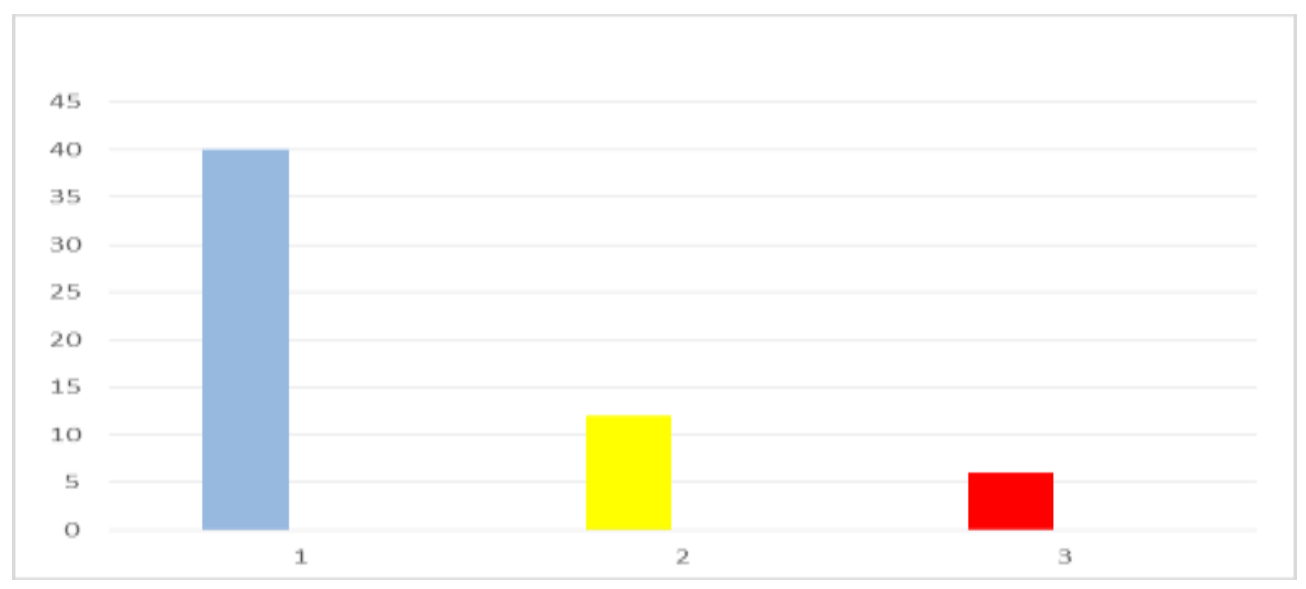

\section{MAIN PART}

22.2\% of rare plants in the Turkestan and Alay mountain ranges the excess part belongs to the Astragal family. Flora's of the combined and Chatkal lists $41.7 \%$ of rare plants are tulips. It is necessary to take protection measures specific to the relevant sector in these areas indicates that. 


\section{TULIPA KAUFMANIANA}

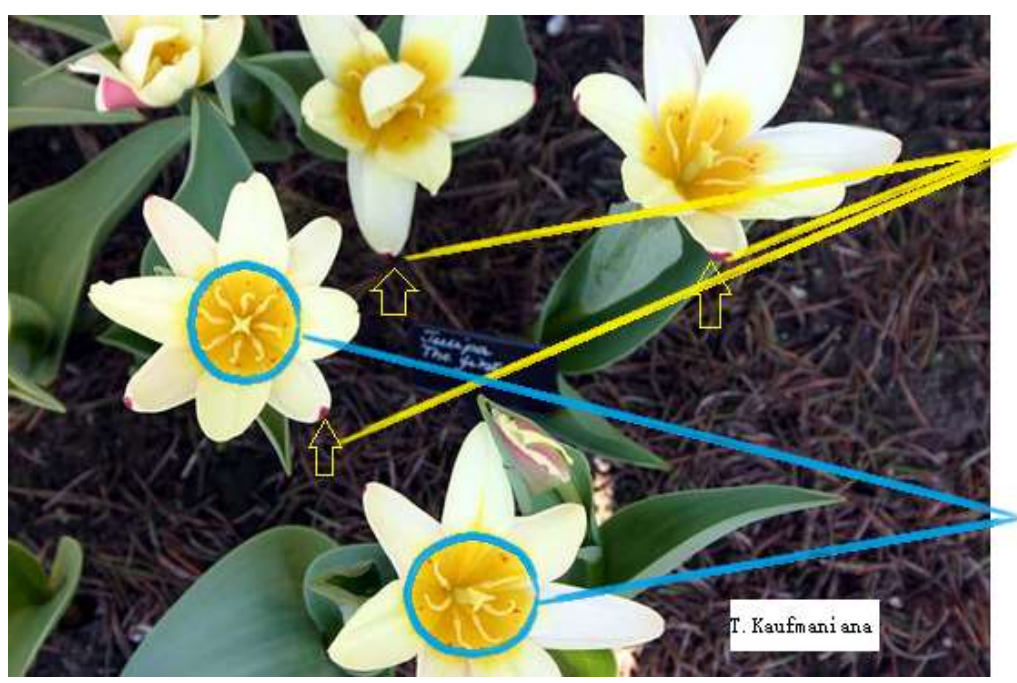

Fig.1.1. Top view of tulip kaufmaniana flower the petals are turned towards the inside of the flower

is yellow from the bottom to the value of the pollen strands, and the top is white

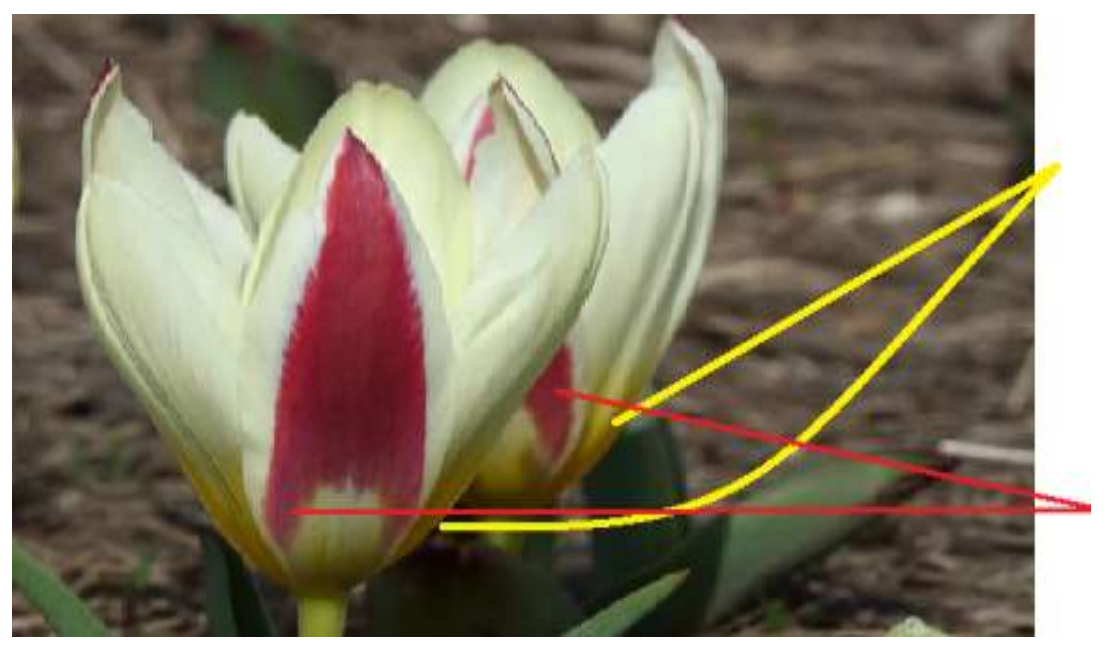

Fig.1.2. Lateral view of the flower

the yellow color on the inside is also partially transferred to the outside

The color of the outer 3 petals and the inner 3 petals are different

partially covered with red like a long triangle on the outside

Fig.1.3. Depending on the degree of openness of the flower, the ratio and concentration of

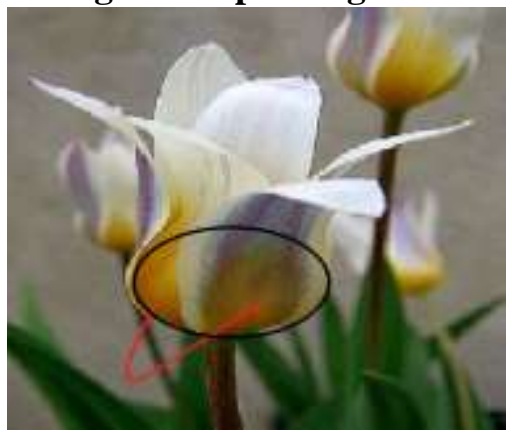
colors will vary. $(3+3$ differs in terms of mutual color )

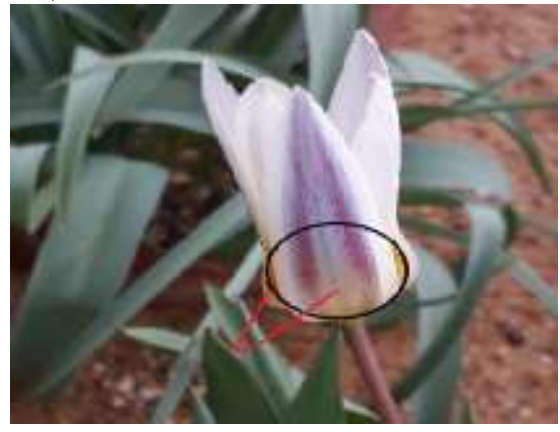


The flowers are solitary, white, yellow, pale yellow, pale red. The base of the flower is yellow, the pollen threads and chandeliers are also yellow. Blooms from March to April.
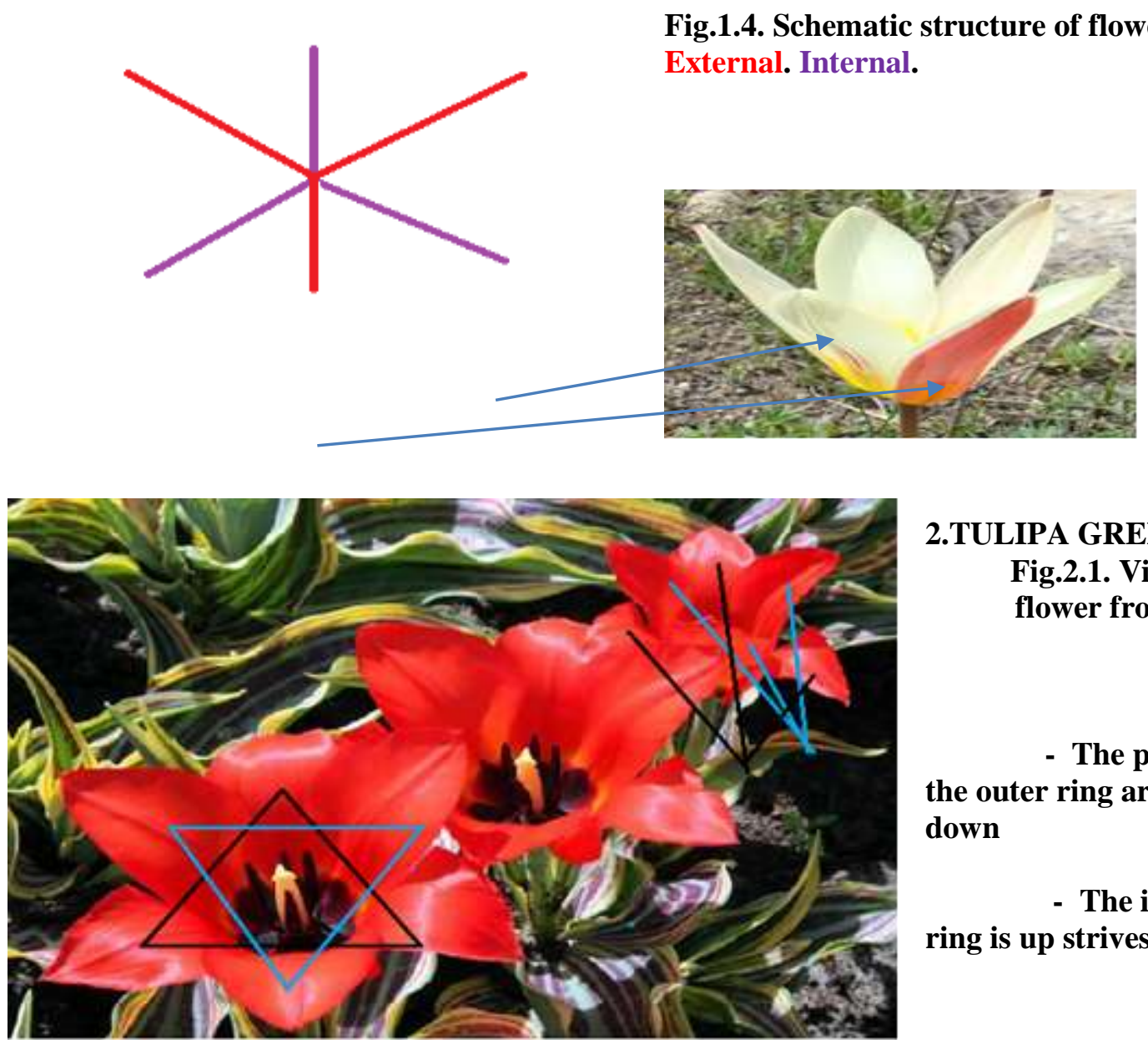

2.TULIPA GREIGI.

Fig.2.1. View of the flower from above.

- The petals in the outer ring are pulled down

\section{- The inner} ring is up strives

The pollen threads and the base of the flower are black, and the pollen grains are yellow.

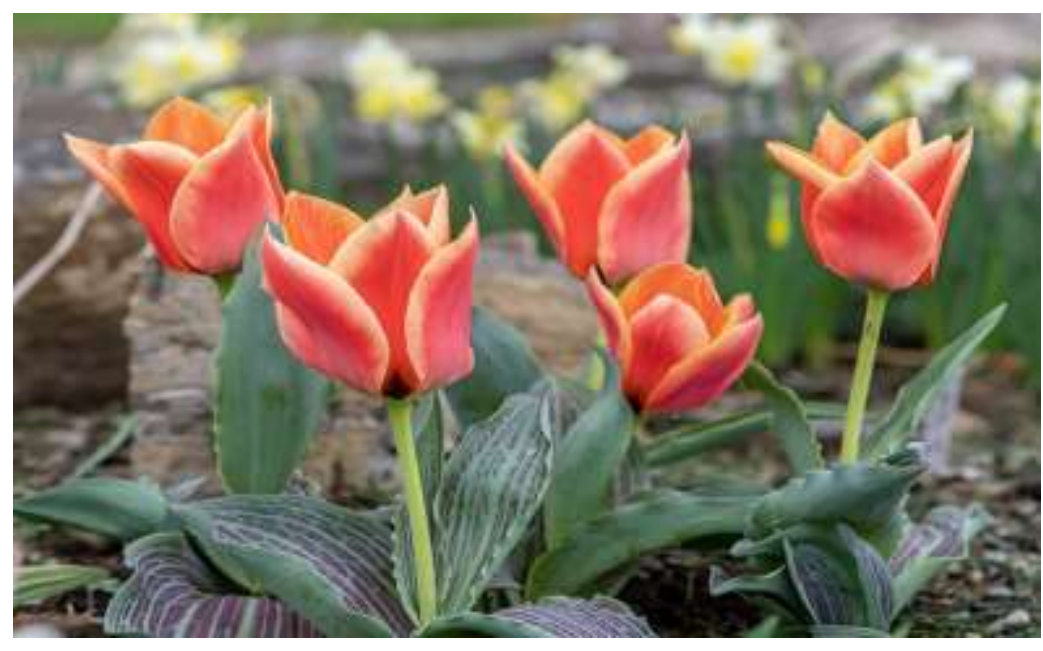

Fig.2.2. Side view of the flower

It is almost

indistinguishable from the inside, but the edges of the petals are a little lighter in color, and the black spot on the bottom is almost invisible. 


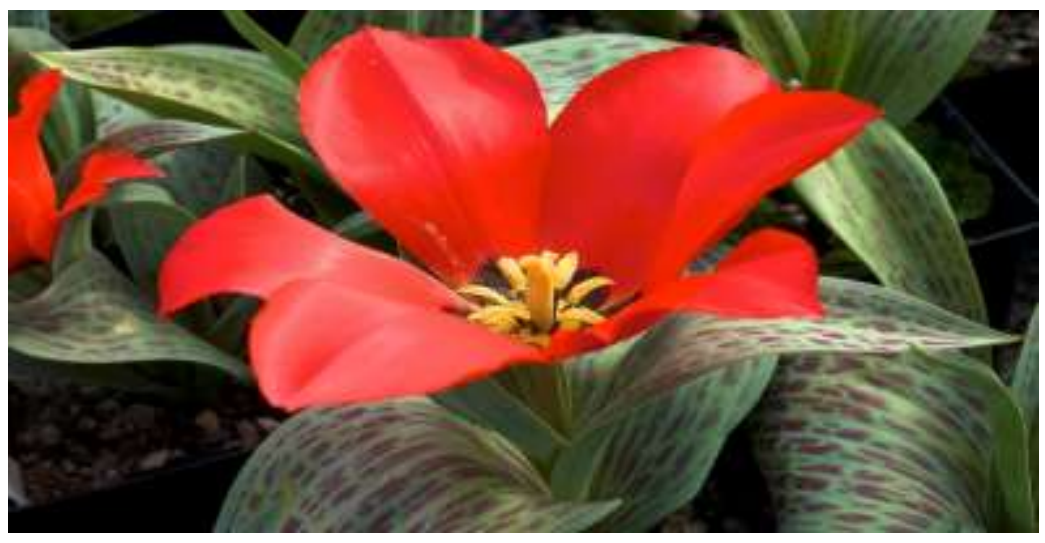

Fig.2.3. T.greigi general, fully open view.

The flowers are solitary, orange, dark red, yellow, with reddish spots, the pollen threads are yellow or black, the pollen grains May.

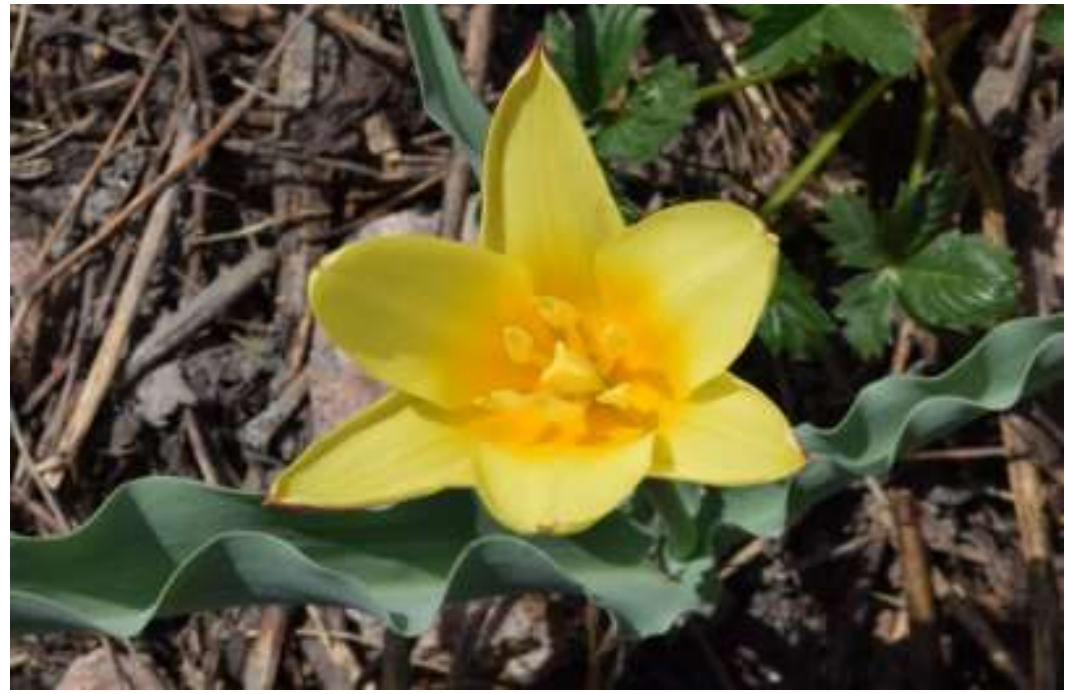

orange, the pollen is yellow. It blooms in May and June

The inside is the same yellow, the bottom is clear.

The flowers are at the base of the leaves and the petiole is hairy. The flowers are solitary, yellow in color, the pollen threads and bottom are

\section{TULIPA DUBIA. \\ Fig.3.1. View of the rose from above.}

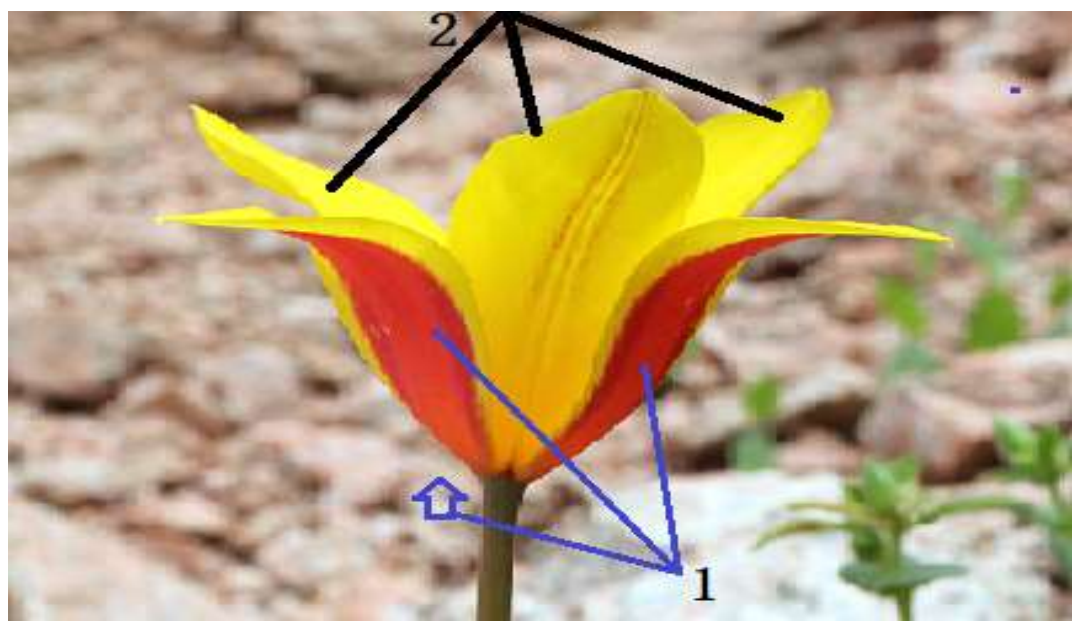

Fig.3.2. Side view of the flower

1- It can be seen from the crowns that are turned towards the outside and their reddish color.

2- The inner ring petals have a parallel line but retain their yellow color. 

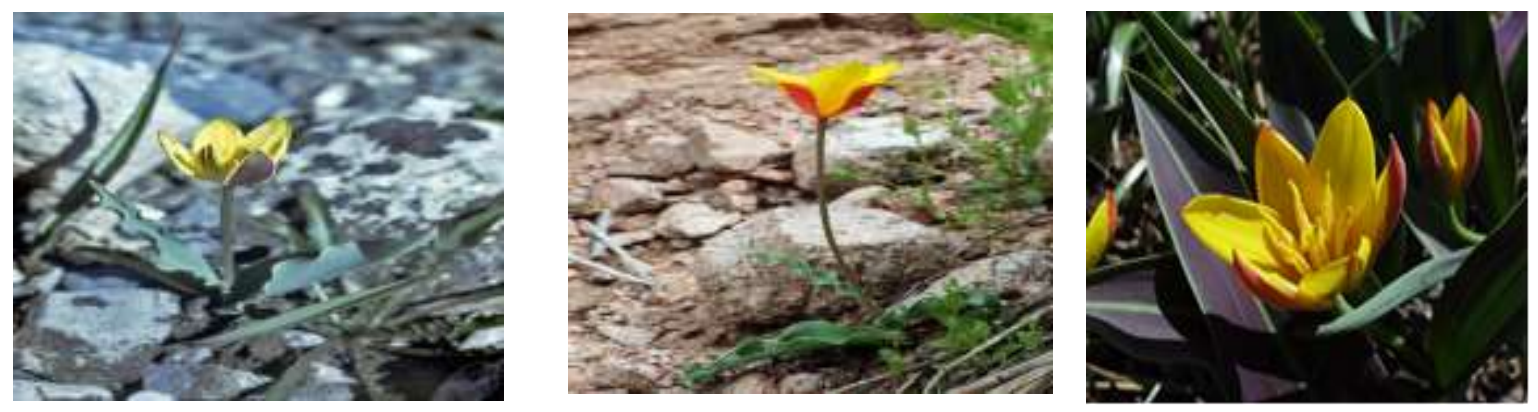

\section{TULIPA SCHARIPOVII.}
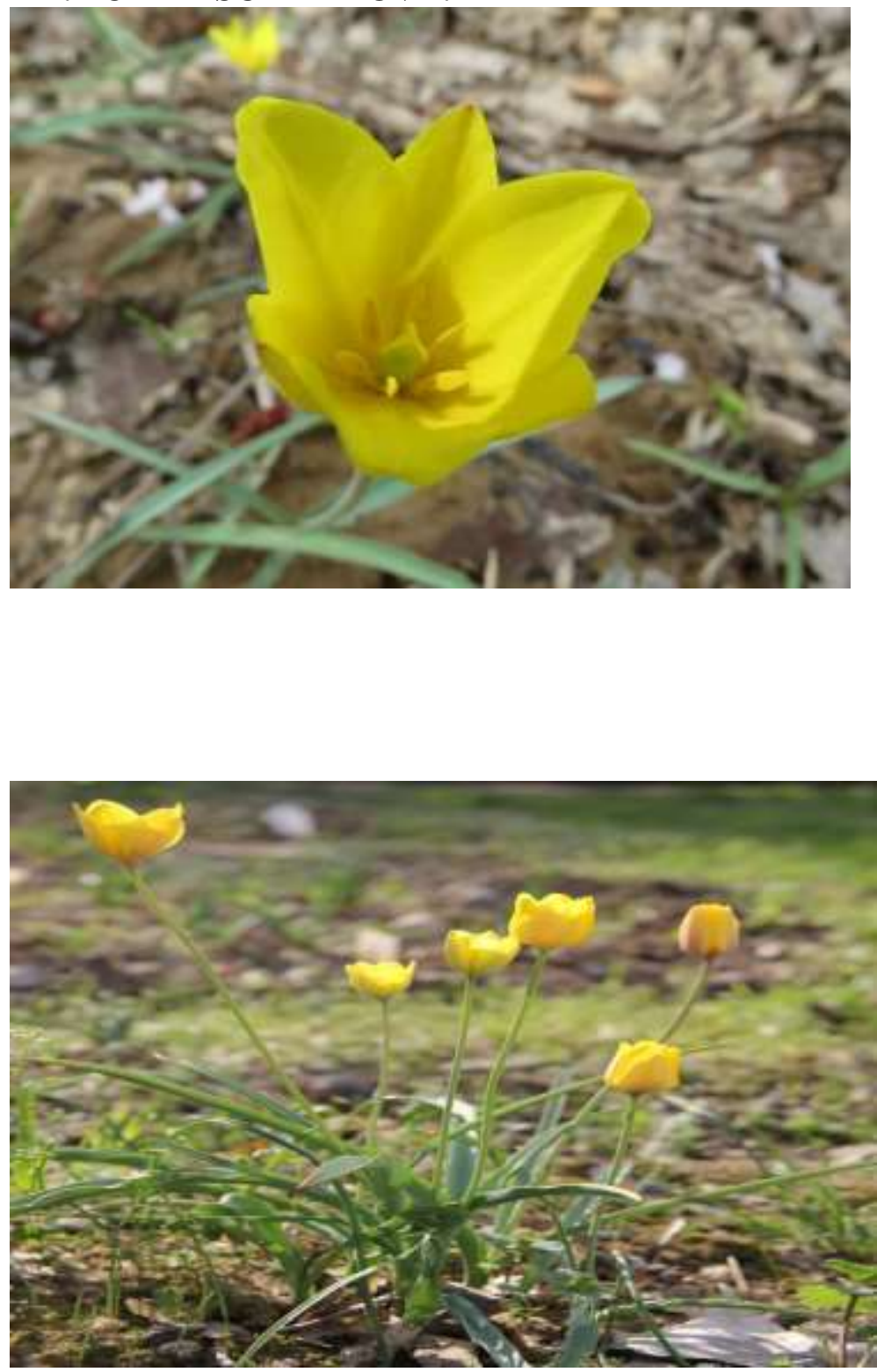

Fig.4.1. View of the rose from above.

If we look at the top of the flower, we see that the whole interior is the same color, which is the difference from the Tulipa dubia flower.

Fig.4.2. Side view of the flower

The same can be said for the side view of the flower. Red spots are rare or absent. 


\section{CONCLUSION}

Finally, the importance of any biological species is measured by its place in the natural environment. That is, it may be civilized, but it is not an important measure. When it comes to the sustainability of a species and its place in the natural chain, we need to maintain its stability in the natural environment. It is advisable to use cultural representatives for any needs.

\section{REFERENCES}

[1]. Tulipa affinis Boschantz., 1961 PA: North-Turk. (Miryakhin, Alexandrova). $328)$.

[2]. Tulipa anadroma Boschantz., 1961 WT: Arsl. (Piryakhin); S-Chel. (Galkina 147, 200, Arifkhanova, Sharipov

[3]. Tulipa bifloriformis Vved., 1935 WT: Nog. (Lepeshkin 31700); Lur. (Azbukin); Chork. (Tojibaev 133, Karimov 012); South-Chatk. (Karimov 0018)

[4]. Tulipa dasystemon (Regel) Regel, 1879 MMA: Arash. (Tojibaev 189); Ars. (Korovin 122177); North-Turk. (Zakrjevskiy 93); East-Al. (Pyataeva, Shafeev); West-Al. (Khaliqov 931).

[5]. Tulipa dasystemonoides Vved., 1935 MMA: Arsl. (Bochkana); North-Turk. (Arifkhanova 1127); East-Al. (Alexadrova, Shonazarov 589); West-Al. (Shonazarov 632).

[6]. Tulipa dubia Vved., 1935 WT: Arash. (Pratov \& Tsukervanik 759, Tojibaev, Karimov 010).

[7]. Tulipa ferganica Vved., 1935 MMA: South-Chatk. (Karimov 011, 012); S-Chel. (Kriltsova 31025, Arifkhanova 184, 386, 427); East-Ferg. (Puchkova 686); East-Al. (Karimov 009, Karimov \& Tojibaev 003).

[8]. Tulipa greigii Regel, 1873 WT: Kur. (Tojibaev 347); Chork. (Tojibaev 317).

[9]. Tulipa intermedia Tojibaev \& J.J. de Groot, 2014 WT: Kur. (Tojibaev, Karimov, n0347), Chork. (Tojibaev, Karimov, Batoshov).

[10]. Tulipa intermedia var. intermedia Tojibaev \&t J.J. de Groot, 2014 WT: Kur. (Tojibaev, n0347), Chork. (Tojibaev, n0161).

[11]. Tulipa intermedia var korolkowioides Tojibaev \&t J.J. de Groot, 2014 WT: Kur. (Tojibaev, n0347), Chork. (Tojibaev, n0347, Karimov, Batoshov, Noraliyeva, sn).

[12]. Tulipa kaufmanniana Regel, 1877 WT: Kur. (Karimov 011, Tojibaev 111); Chork. (Karimov 098

[13]. Red Book of the Republic of Uzbekistan all editions

[14]. Shukrullo, F. (2020). GULSAFSARDOSHLAR OILASI VAKILLARINING FARGO'NA VODIYSIDAGI KAMYOB TURLARI: IRIS WINKLERII. Science and Education, 1(1).

[15]. Ugli, F. S. F., \& Ugli, N. M. G. (2020). THE EFFECT OF CERTAIN SUBSTANCES ON THE GROWTH OF PUMPKIN SEEDS. Science and Education, 1(4). 